\title{
Design, analysis and reporting of active-control randomised trials: a systematic review
}

\author{
Lang'o Odondi, Chris Metcalfe, Jonathan Sterne \\ From 2nd Clinical Trials Methodology Conference: Methodology Matters \\ Edinburgh, UK. 18-19 November 2013
}

\section{Background}

Active-control randomised trials are typically conducted to evaluate the benefit of a novel intervention relative to an established treatment. The appropriate design, analysis and conclusions depend upon whether the novel intervention is anticipated to be superior or non-inferior on the primary outcome measure. But despite their widespread application, active-control studies are often poorly understood, improperly applied, and incorrectly interpreted.

\section{Methods}

We systematically review recently published active-control trials in a high-impact journal, to appraise their design, analysis and the conclusions drawn. All trials published in 2010 were identified and data extracted in duplicate using a standard proforma. Meta-analyses examined differences in the average treatment effect between superiority and non-inferiority studies.

\section{Results}

Thirty-seven studies met our inclusion criteria; 12 designed as non-inferiority studies. Non-inferiority studies did not have larger sample sizes (median=702) compared to superiority studies (median=725). Margins of non-inferiority were explicitly defined for the noninferiority studies. All studies employed an intention-totreat as primary analysis, with one non-inferiority study including per-protocol secondary analysis. On average, superiority studies favoured the novel treatment $(\mathrm{OR}=0.75)$, which was not the case for non-inferiority studies $(\mathrm{OR}=1.31)$. Few studies swapped between the superiority and non-inferiority approaches as the study progressed, with no evidence that those swaps were in response to the results obtained.

University of Bristol, Bristol, UK

(C) 2013 Odondi et al; licensee BioMed Central Ltd. This is an Open Access article distributed under the terms of the Creative Commons Attribution License (http://creativecommons.org/licenses/by/2.0), which permits unrestricted use, distribution, and reproduction in any medium, provided the original work is properly cited.

\section{Conclusion}

These active-control studies were found to have appropriate sample size targets, with no evidence of noninferiority studies being larger. Only one non-inferiority study used per-protocol analysis as suggested in the CONSORT guidelines. There was no evidence of reporting bias due to switches between superiority and noninferiority approaches.

Published: 29 November 2013

doi:10.1186/1745-6215-14-S1-0123

Cite this article as: Odondi et al:: Design, analysis and reporting of active-control randomised trials: a systematic review. Trials 2013 14(Suppl 1):0123.
Submit your next manuscript to BioMed Central and take full advantage of:

- Convenient online submission

- Thorough peer review

- No space constraints or color figure charges

- Immediate publication on acceptance

- Inclusion in PubMed, CAS, Scopus and Google Scholar

- Research which is freely available for redistribution \\ () Biomed Central}

